\title{
Significance of Proliferation Markers and Prognostic Factors in Egyptian Patients with Multiple Myeloma
}

\author{
Iman A Abdelgawad ${ }^{1 *}$, Noha H Radwan'1, Roxan E Shafik ${ }^{1}$, Hala A Shokralla ${ }^{2}$
}

\begin{abstract}
Background: Multiple myeloma (MM) is influenced by genetic and micro-environmental changes. Malignant plasma cells produce an abnormal monoclonal immunoglobulin, as well as cytokines, such as IL-10 and IL-6 which stimulate cells of the bone marrow microenvironment (BMM) and cause dysfunction and failure of many organs. B cell activating factor (BAFF), IL6 and IL10 are known to influence the growth and survival of malignant clones. Aim: The objectives of the present study were to investigate the circulating levels of BAFF , IL-10 and IL-6, correlate them with well-known parameters of disease activity in patients with MM, and to detect their impact on patients' survival. Materials and Methods: This study was conducted on 89 newly diagnosed MM patients and seventy apparently healthy volunteers as a normal control group. BAFF, IL6, IL10 were measured by ELISA for both groups and survival analysis was performed for all patients. Results: Studied markers were higher in the MM patients compared to the normal control subjects. Patients survival was improved by high serum BAFF levels. Conclusions: High levels of BAFF were found to improve patients' survival. BAFF and IL-6 can be considered probable diagnostic markers for MM.
\end{abstract}

Keywords: Multiple myeloma - BAFF - IL6 - IL10

Asian Pac J Cancer Prev, 17 (3), 1351-1355

\section{Introduction}

Multiple genetic and micro-environmental changes are known to contribute to the pathogenesis of the malignant proliferation of a plasma cell clone causing multiple myeloma (MM) (Kyle et al., 2003). Nearly 230,000 people are living with MM worldwide (globocan , 2012), with $47 \%$ five year survival-rate (multiple-myeloma/statistics, 2015). MM can cause impaired humoral immunity $(80 \%)$, skeletal disease $(70 \%)$, anemia $(40 \%)$, and renal impairment (20\%) (Sirohi et al., 2004).

Malignant plasma cells produce an abnormal monoclonal immunoglobulin, as well as cytokines, such as IL-10 and IL-6 which stimulate cells of the bone marrow microenvironment (BMM) and cause dysfunction and failure of many organs (Tricot,2000).

IL-10 is a powerful inducer for immunoglobulin secretion by the plasma cells. It is produced by activated T cells, monocytes, and mostly by normal and malignant B cells (Moore et al., 1993). It acts as a proliferation factor for B cells, and is involved in their differentiation to plasma cells. Furthermore, it seems to act as a growth factor for MM cells (Kovaks et al., 2010). IL-10 has been implicated in the pathogenesis of other malignant B-cell neoplasms as chronic lymphocytic leukemia (Gupta et al., 2012).
IL-6 is produced by B cells, T cells (Horii et al., 1988), fibroblasts (Weissenbach et al.,1980), monocytes (Aarden et al., 1987), and some tumor cells, (Okada et al., 1988). It promotes the population expansion and activation of $\mathrm{T}$ cells, the differentiation of $\mathrm{B}$ cells, and regulation of the acute-phase response (Hirano et al., 2014). It is involved in autoimmunity, inflammation, and lymphoid malignancies (DuVillard et al., 1995) and acts as an important growth factor for MM by inhibiting apoptosis induced by growth factors withdrawal, and by triggering the expression of cell-death receptor Fas (Tinhofer et al., 2000).

BAFF is a tumor necrosis factor (TNF) family member, essentially expressed by monocytes, dendritic cells, and some T cells (Okada et al., 1988). It is critical for maintenance of normal B-cell development (Horii et al., 1988) and is considered a survival factor for immature, naive, and activated B cells (Okada et al., 1988). It is produced as both a membrane-bound and a soluble protein (Weissenbach et al.,1980). Myeloma cells express BAFF and its receptors (Okada et al., 1988) that are primarily produced by the BMM (Moreaux et al., 2004).

Immunoglobulins (Igs) are continually produced throughout B-cell development and their terminal differentiation into plasma cells. Immunoglobulins are made up of mirror image identical light and heavy chains. The amount of $x$ light chain produced is almost twice that 
of $\lambda$ (Bradwell et al., 2001).

Aim of the work: Is to compare the serum levels of BAFF, IL-10 and IL- 6 between the MM patients and the normal control group. Also to study their impact on the survival of the MM patients. Comparing the tested markers with some prognostic factors of MM is also one of the aims of this study.

\section{Materials and Methods}

\section{Patients}

This study was conducted on consecutive 89 newly diagnosed MM patients who presented to the outpatient clinic at the medical oncology department, National Cancer Institute, Cairo University. All eligible new cases were included in the study. The study lasted 3 years from January 2012 till December 2014. All patients were proven to have MM according to the standard criteria of the International Myeloma Working Group (IMWG) (Bird et al., 2011).

Seventy apparently healthy volunteers were included in the study as a normal control group.

The study protocol was approved by the Scientific Research Committee and Institutional Review Board at the National Cancer Institute, Cairo University, Egypt.

Written informed consent was obtained before enrollment into the study according to ethics committee.

Inclusion criteria: $i$ ). Patients proven to have MM. ii). Newly diagnosed patients prior to any therapeutic intervention. iii). Either sex was eligible. vi). Age: 18-70 years. $v$ ). Performance status (ECOG Scale) $\leq 2$ (Oken et al., 1982). vi). Life expectancy of at least 6 months.

Exclusion criteria: $i$ ). Patients with serious concomitant systemic disorders, current or previous other malignancies at time of diagnosis. ii). Patients with uncontrolled infectious diseases.

Treatment was initiated in all patients with active myeloma fulfilling the CRAB criteria, (hypercalcaemia $>11.0 \mathrm{mg} / \mathrm{dl}$ ), creatinine $>2.0 \mathrm{mg} / \mathrm{ml}$, anaemia $(\mathrm{Hb}<10$ $\mathrm{g} / \mathrm{dl}$ ), active bone lesions, and in those symptomatic due to the underlying disease in form of VAD (vincristine, adriamycin\& dexamethasone) or VD (bortezomib \& dexamethasone) (Moreau et al., 2013).

The part of statistical analysis is missing from this copy, please insert the following at the end of the methodology part:

\section{Statistical analysis}

Data analysis was done by using IBM SPSS advanced statistics version 20 (SPSS Inc., Chicago, IL). The descriptive measures were presented in frequency and percentages. For quantitative data, comparison between two groups was done using Mann-Whitney (non-parametric t-test), and between 3 groups, Kruskall Wallis (non-parametric ANOVA) was used. The Receiver Operating Characteristic (ROC) curve was used for prediction of cut off values. Sensitivity, specificity, positive predictive value (PPV) and negative predictive values (NPV) were calculated for the different markers used. Survival analyses were done using the KaplanMeier method. Comparisons between two survival curves were done using log-rank test. Overall survival (OS) was defined as the time in months between the date of diagnosis and death or loss to follow up. Disease -free survival (DFS) was defined as the time in months between the date of treatment and documented recurrence, progression or death. Cut off values used for the prediction of patients' survival were chosen as the value of the median level of the measured variable among the malignant cases. P-value of $\leq 0.05$ was considered significant.

\section{Results}

Patients' characteristics are mentioned in Table (1).

On Comparing the serum levels of IL-10, BAFF, IL-6, and $\beta 2 \mathrm{M}$ between the $\mathrm{MM}$ and the normal control groups, all the tested markers were statistically significantly higher in the MM compared to the normal control group ( $p$ $<0.001)$ each. Differences in clinical parameters according to albumin, $\beta 2 \mathrm{M}$ and IL- 6 levels in the MM patients are shown in table (2), while the diagnostic performance of the different studied markers is shown in Table 3.

On comparing some prognostic factors of multiple myeloma as $\beta 2 \mathrm{~m}$, albumin, creatinine, hemoglobin, BAFF, IL-10 and IL- 6 according to the type of immunoglobulin,

\section{Table 1. Patients' Characteristics}

\begin{tabular}{|c|c|}
\hline Variable & N $89(\%)$ \\
\hline Age (median and interquartile range) & $54(45-59)$ \\
\hline \multicolumn{2}{|l|}{ Sex } \\
\hline Male & $56(63)$ \\
\hline Female & $33(37)$ \\
\hline \multicolumn{2}{|l|}{ Albumin } \\
\hline$<3.5 \mathrm{~g} / \mathrm{dl}$ & $38(43)$ \\
\hline$\geq 3.5 \mathrm{~g} / \mathrm{dl}$ & $51(57)$ \\
\hline \multicolumn{2}{|l|}{ Serum creatinine } \\
\hline$<1.2 \mathrm{mg} / \mathrm{dl}$ & $58(65)$ \\
\hline$\geq 1.2 \mathrm{mg} / \mathrm{dl}$ & $31(35)$ \\
\hline \multicolumn{2}{|l|}{$\beta 2 \mathrm{~m}$} \\
\hline$<2.7 \mathrm{mg} / \mathrm{L}$ & $24(27)$ \\
\hline$\geq 2.7 \mathrm{mg} / \mathrm{L}$ & $65(73)$ \\
\hline \multicolumn{2}{|l|}{ Corrected calcium } \\
\hline$<10.5 \mathrm{mg} / \mathrm{dl}$ & $81(91)$ \\
\hline$\geq 10.5 \mathrm{mg} / \mathrm{dl}$ & $8(9)$ \\
\hline \multicolumn{2}{|l|}{ Type of immunoglobulin } \\
\hline IgG & $73(82)$ \\
\hline $\operatorname{IgA}$ & $16(18)$ \\
\hline \multicolumn{2}{|l|}{ Type of light chain } \\
\hline Kappa & $58(65)$ \\
\hline Lambda & $31(35)$ \\
\hline \multicolumn{2}{|l|}{ Type of Ig with corresponding light chain } \\
\hline $\operatorname{IgG}-\mathrm{K}$ & $51(57)$ \\
\hline IgG- $\lambda$ & $22(25)$ \\
\hline IgA-K & $7(8)$ \\
\hline $\operatorname{IgA}-\lambda$ & $9(10)$ \\
\hline \multicolumn{2}{|l|}{ MM Staging (ISS) } \\
\hline I & $22(25)$ \\
\hline II & $20(22)$ \\
\hline II & $47(53)$ \\
\hline \multicolumn{2}{|l|}{ Plasma cell \% } \\
\hline$<30$ & $22(25)$ \\
\hline$\geq 30$ & $67(75)$ \\
\hline
\end{tabular}

IgG: Immunoglobulin G; IgA: Immunoglobulin A; K: Kappa; $\lambda$ : Lambda; MM: Multiple myeloma; ISS: International staging system 
Table 2. Differences in clinical parameters according to albumin, $\beta 2 M$ and IL-6 levels in the MM patients

\begin{tabular}{|c|c|c|c|c|c|c|c|c|c|}
\hline & $\begin{array}{c}\text { Albumin } \\
<3.5 \mathrm{~g} / \mathrm{dl} \\
(\mathrm{n}=38)\end{array}$ & $\begin{array}{c}\text { Albumin } \\
\geq 3.5 \mathrm{~g} / \mathrm{dl} \\
(\mathrm{n}=51)\end{array}$ & $P$ value & $\begin{array}{c}\beta 2 \mathrm{M} \\
<2 \mathrm{mg} / 1 \\
(\mathrm{n}=14)\end{array}$ & $\begin{array}{c}\beta 2 \mathrm{M} \\
\geq 2 \mathrm{mg} / 1 \\
(\mathrm{n}=75)\end{array}$ & $P$ value & $\begin{array}{c}\text { IL-6 } \\
<7.4 \mathrm{pg} / \mathrm{ml} \\
(\mathrm{n}=16)\end{array}$ & $\begin{array}{c}\text { IL-6 } \\
\geq 7.4 \mathrm{pg} / \mathrm{ml} \\
(\mathrm{n}=73)\end{array}$ & $P$ value \\
\hline $\begin{array}{l}\text { Albumin } \\
(3.5-5.2 \mathrm{~g} / \mathrm{dl})\end{array}$ & & & & $\begin{array}{c}3.9 \\
(3.2-4.5)\end{array}$ & $\begin{array}{c}3.5 \\
(2.8-4.2)\end{array}$ & 0.271 & $\begin{array}{c}4 \\
(3.8-4.4)\end{array}$ & $\begin{array}{c}3.4 \\
(2.7-4)\end{array}$ & $0.015^{*}$ \\
\hline $\mathrm{Hb}$ conc & $\begin{array}{c}9.2 \\
(8-10.6)\end{array}$ & $\begin{array}{c}10.9 \\
(8.9-12.6)\end{array}$ & $0.004 *$ & $\begin{array}{c}11.6 \\
(10.6-12.6)\end{array}$ & $\begin{array}{c}9.5 \\
(8.4-11.2)\end{array}$ & $0.01 *$ & $\begin{array}{c}12 \\
(10.7-13)\end{array}$ & $\begin{array}{c}9.4 \\
(8.3-11)\end{array}$ & $0.002 *$ \\
\hline $\begin{array}{l}\beta 2 \mathrm{M} \\
(1.21-2.70 \mathrm{mg} / \mathrm{l})\end{array}$ & $\begin{array}{c}6.9 \\
(3.9-10.4)\end{array}$ & $\begin{array}{c}5.2 \\
(2.2-7.8)\end{array}$ & 0.09 & & & & $\begin{array}{c}2.2 \\
(1.7-2.6)\end{array}$ & $\begin{array}{c}7 \\
(4-9.7)\end{array}$ & $<0.001 *$ \\
\hline $\begin{array}{l}\text { Creatinine } \\
(0.2-1.2 \mathrm{mg} / \mathrm{dl})\end{array}$ & $\begin{array}{c}0.97 \\
(0.8-1.9)\end{array}$ & $\begin{array}{c}0.9 \\
(0.7-1.3)\end{array}$ & 0.208 & $\begin{array}{c}0.89 \\
(0.7-1)\end{array}$ & $\begin{array}{c}0.93 \\
(0.75-1.6)\end{array}$ & 0.163 & $\begin{array}{c}0.75 \\
(0.65-0.99)\end{array}$ & $\begin{array}{c}1 \\
(0.8-1.6)\end{array}$ & $0.011 *$ \\
\hline BM plasma cells & $\begin{array}{c}17 \\
(7-30)\end{array}$ & $\begin{array}{c}13 \\
(4.25-34)\end{array}$ & 0.881 & $\begin{array}{c}7 \\
(1-13)\end{array}$ & $\begin{array}{c}17 \\
(6-31)\end{array}$ & $0.033^{*}$ & $\begin{array}{c}15 \\
(2.5-28)\end{array}$ & $\begin{array}{c}15 \\
(6-32)\end{array}$ & 0.525 \\
\hline
\end{tabular}

Significant; Median and interquartile range in parenthesis; Hb: Hemoglobin; $\beta 2$ M: Beta 2 microglobulin; BM: Bone marrow; IL-6: Interleukin 6; Hb conc in men: 14.0-17.5 g/dL; Hb conc in women: 12.3-15.3 g/dL

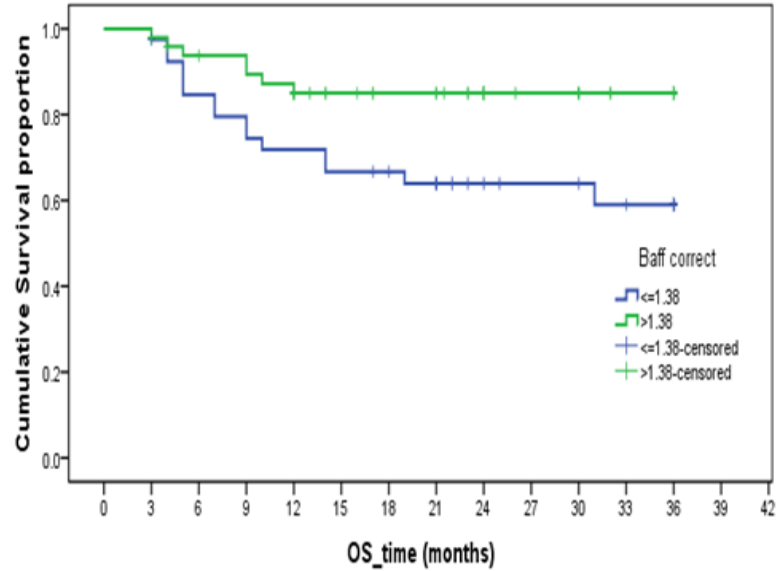

Figure 1. Relation between BAFF Concentration and Overall Survival

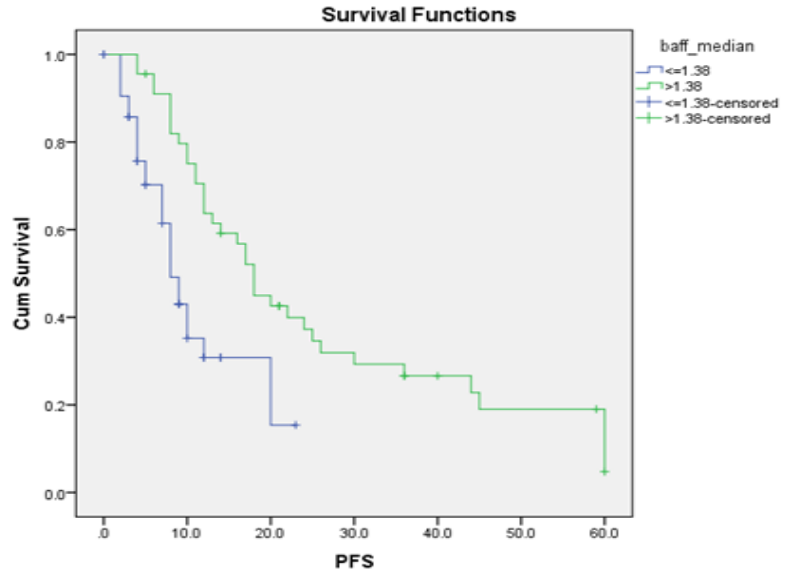

Figure 2. Relation between BAFF and DFS

Table 3. Diagnostic performance of the different markers for the differentiation between multiple myeloma and normal control groups

\begin{tabular}{|c|c|c|c|c|}
\hline & $\begin{array}{c}\text { BAFF } \\
\text { Cut off } 1 \mathrm{ng} / \mathrm{ml}\end{array}$ & $\begin{array}{c}\text { IL-10 } \\
\text { cut off } 4.8 \mathrm{pg} / \mathrm{ml}\end{array}$ & $\begin{array}{c}\text { IL-6 } \\
\text { cut off } 4.2 \mathrm{pg} / \mathrm{ml}\end{array}$ & $\begin{array}{c}\beta 2 \mathrm{M} \\
\text { cut off } 2 \mathrm{mg} / 1\end{array}$ \\
\hline Sensitivity $\%$ & 100 & 91 & 99 & 87 \\
\hline $95 \% \mathrm{CI}$ & $(95-100)$ & $(83-96)$ & $(98-99)$ & $(78-93)$ \\
\hline Specificity $\%$ & 88 & 64 & 96 & 74 \\
\hline $95 \%$ CI & $(75-95)$ & $(49-77)$ & $(85-99)$ & $(59-84)$ \\
\hline PPV\% & 94 & 82 & 98 & 84 \\
\hline $95 \% \mathrm{CI}$ & $(86-97)$ & $(73-89)$ & (91 - 99) & $(75-91)$ \\
\hline NPV\% & 100 & 80 & 98 & 78 \\
\hline $95 \%$ CI & $(90-100)$ & $(64-90)$ & $(88-99)$ & $(64-88)$ \\
\hline DA $\%$ & 95 & 82 & 97 & 82 \\
\hline
\end{tabular}

B2 M: Beta 2 microglobulin, BAFF: B-cell-activating factor, IL 10: Interleukin 10, IL-6: Interleukin 6, CI: Confidence interval, PPV: Positive predictive value, NPV: Negative predictive value, DA: Diagnostic accuracy

type of light chain, and the stage of the disease; creatinine, BAFF, and IL-6 significantly showed the highest concentrations with the presence of lambda compared to kappa light chains $(\mathrm{p}=0.009,0.004$, and 0.003 ) respectively. Higher levels of $\beta 2 \mathrm{~m}$ and IL-6 and lower levels of albumin and hemoglobin were significantly associated with advanced stage $(\mathrm{p}<0.001)$ each. Higher levels of creatinine and lower levels of hemoglobin were significantly associated with IgA MM compared to IgG MM ( $\mathrm{p}=0.05$ and 0.013$)$ respectively.
As regards survival, the different diagnostic and prognostic parameters were studied in relation to both (OS) and (DFS).

\section{Overall survival (OS)}

The follow up period ranged between 1 and 36 months. At the end of the study ( 3 years), OS was $74 \%$, and at 5 years, $72.7 \%$ of the patients are expected to be still alive.

Eighty five $\%$ of patients with high BAFF levels ( $>1.38$ $\mathrm{ng} / \mathrm{ml}$ ) were still alive after a total period of 24 months 
compared to only $64 \%$ of patients with low BAFF levels (Figure 1). So, BAFF level could be considered a strong predictor for OS in MM $(\mathrm{p}<0.023)$.

\section{Disease free survival (DFS)}

The median DFS was 12 months; with 76\% 3-years DFS and $45.7 \%$ at 5 years.

BAFF was also found to be strongly related to DFS $(\mathrm{p}<0.001)$. Median DFS of patients with higher levels $(>1.38 \mathrm{ng} / \mathrm{ml})$ was better than those with low levels $(\leq 1.38$ $\mathrm{ng} / \mathrm{ml}$ ) (18 vs. 8 months) as shown in Figure (2). Lower levels of serum both creatinine and plasma cell infiltration of BM and normal hemoglobin levels were associated with better DFS ( $p=0.01,0.05$ and 0.01 ) respectively.

$\beta 2 \mathrm{~m}$ was found to be an independent prognostic factor for DFS ( $\mathrm{p}=0.006$ ). Median DFS of low $\beta 2 \mathrm{M} \leq 2 \mathrm{mg} / \mathrm{l}$ was 36 months compared to only 11 months for patients with higher levels $(\mathrm{p}=0.02)$.

No other statistically significant relations were detected between survival and other prognostic factors of MM as; levels of ALP, albumin, calcium, IL 6, IL10, type of Ig and light chain, and stage of the disease.

\section{Discussion}

BAFF is suggested to stimulate the myeloma cells through an autocrine loop (Moreaux et al., 2004).

Depending on the B cell maturation stage, BAFF was reported to induce the anti-apoptotic proteins Bcl-2 and to reduce the pro-apoptotic protein Bak (Batten et al., 2000).

From all the studied proliferation markers, higher levels of serum BAFF ( $>1.38 \mathrm{ng} / \mathrm{ml})$ were found to be significantly associated with longer OS and DFS among myeloma patients $(\mathrm{p}=0.023)$, which is contradictory to the results of other investigators, who suggested BAFF to be a possible prognostic factor and a strong predictor for OS in MM as it was associated with reduced survival (Lemancewicz et al., 2013, Hengeveld et al., 2015).These contradictory results may be due to the different ethnic population studied, or different kind of therapy received.

As BAFF regulates and enhances innate and adaptive immunity (Caers et al., 2008), it may lead to improvement of MM patients' survival which might support our results. BAFF has also been identified as one of the main survival factors for healthy plasma cells as well as MM cells (Caers et al., 2008). So, more studies with larger sample sizes are recommended to monitor BAFF serum levels before and after treatment, to investigate the predominant role of BAFF on both healthy and malignant plasma cells and to study the different signaling pathways to reach a more accurate conclusion about the impact of BAFF on the survival of MM patients.

Higher serum levels of BAFF together with IL-6, IL10 and $\beta 2 \mathrm{~m}$ were found to be significantly higher in $\mathrm{MM}$ patients compared to the normal control group $(\mathrm{P}<0.001)$, which falls in line with previous reports (Wang et al., 2011,Fragioudaki et al., 2012,Alexandrakis et al., 2013) . Also, IL-6 had the best diagnostic performance of the tested markers, followed by BAFF.

Higher BAFF levels together with IL-6 and serum creatinine were also detected in patients with lambda light chain $(\mathrm{P}=0.033)$ compared to patients with kappa light chain, although, normally, the amount of $x$ light chain produced is almost twice that of $\lambda$ (Bradwell et al., 2001). The structural differences between both types may relate to their different biological activities and relations with other prognostic factors, as kappa light chains are described as monomeric, which can exist as a non-covalently linked dimer, while $\lambda$ light chains are usually dimeric with covalent bonds between them (Solomon et al., 1976).

Regarding the type of immunoglobulin, IgA MM was significantly associated with higher levels of creatinine, and lower levels of hemoglobin compared to IgG MM.

Evidence indicates that $\operatorname{Ig}$ A myeloma is different from IgG myeloma in terms of disease characteristics (Sirohi et al., 2001). In an international study of staging in myeloma, IgA patients had a median overall survival of 40 months compared with 49 months for IgG patients; the reason for this difference was not explored (Greipp et al., 2005 ).

$\beta 2 \mathrm{~m}$ was found to be an independent prognostic factor for DFS as higher levels significantly reduced median DFS $(\mathrm{p}=0.02)$. It was significantly higher with advanced stage $(\mathrm{P}<0.001)$. It seems that $\beta 2 \mathrm{~m}$ has a negative impact on the patients' outcome as it reflects the tumor burden and increases in case of renal insufficiency (Pika et al., 2008). Some Bence Jones MM (BJMM) cases are associated with a-more rapid onset of tubular and glomerular damage (Solomon, 1986) resulting in a reduced glomerular filtration rate and diminished clearance of $\beta 2 \mathrm{~m}$.

Anemic patients, higher plasma cell counts and higher serum creatinine levels showed their negative impacts on DFS as previously shown in other publications (Bird et al., 2011).

Albumin and $\beta 2 \mathrm{~m}$ are routinely used to classify MM. Serum $\beta 2 M$ reflects not only tumor mass and renal function but also some immune functions (Durie et 1 ., 2003). IL-6 was suggested to be a significant prognostic marker in MM based on its strong correlation with other prognostic factors (Lauta et al., 2003), which supports our finding that IL-6 was significantly higher with advanced stage.

We divided the MM group according to the serum levels of albumin, $\beta 2 \mathrm{~m}$, IL-6, IL-10 and BAFF at the chosen cut off levels $(<3.5 \mathrm{~g} / \mathrm{dl},<2 \mathrm{mg} / 1,<7.4 \mathrm{pg} / \mathrm{ml}$, $<5.7 \mathrm{pg} / \mathrm{ml}$ and $1.3 \mathrm{ng} / \mathrm{ml}$ respectively into 2 groups and compared both groups according to some prognostic factors of MM (hemoglobin, ALP, BM plasma cell count, type of immunoglobulin, and type of light chain). Higher albumin levels $(\geq 3.5 \mathrm{~g} / \mathrm{dl})$ were significantly associated with higher hemoglobin concentrations. Lower $\beta 2 \mathrm{~m}$ concentrations $(<2 \mathrm{mg} / \mathrm{l})$ were significantly associated with higher hemoglobin concentrations and lower BM plasma cell counts, while lower levels of IL-6 ( $<7.4 \mathrm{pg}$ / $\mathrm{ml})$ were significantly associated with higher albumin and hemoglobin and lower $\beta 2 \mathrm{~m}$, and creatinine levels. So, albumin, $\beta 2 \mathrm{~m}$ and IL- 6 are suggested to be included in a panel to be used for classification and prognosis stratification among MM patients, which needs further studies on a wider scale to validate such results. These results are consistent with other investigators (Kim et al., 2010).

In conclusion, High serum levels of BAFF were found 
Significance of Proliferation Markers and Prognostic Factors in Egyptian Patients with Multiple Myeloma

to improve patients' survival. Further studies are still needed to validate these results. The presence of high levels of $\beta 2 \mathrm{~m}$ was found to impact the patients' survival which is matching to our expectations as $\beta 2 \mathrm{~m}$ reflects the tumor burden.

Albumin, $\beta 2 \mathrm{~m}$ and IL-6 are suggested to be included in a panel to be used for classification of MM due to their significant relations with many prognostic factors.

More studies including larger sample size and longer durations of follow up are recommended to validate such results.

\section{References}

Aarden L, DeGroot E, Schaap O, et al (1987). Production of hybridoma growth factor by human monocytes. Eur $J$ Immunol, 17, 1411-6.

Alexandrakis M, Roussou P, Pappa C, et al (2013). Relationship between Circulating BAFF Serum Levels with Proliferating Markers in Patients with Multiple Myeloma. Biomed Res Int, 389579.

Batten M, Groom J, Cachero G, et al (2000). BAFF mediates survival of peripheral immature B lymphocytes. J Exp Med, 192,1453-66.

Bird M, Owen G, D'Sa S, et al (2011). Guidelines for the diagnosis and management of multiple myeloma. $\mathrm{Br} J$ Haematol, 154, 32-75.

Bradwell R, Carr-Smith D, Mead P, et al (2001). Highly sensitive, automated immunoassay for immunoglobulin free light chains in serum and urine. Clin Chem, 47, 673-80.

Caers J, Van Valckenborgh E, Menu E, et al (2008). Unraveling the biology of multiple myeloma disease: cancer stem cells, acquired intracellular changes and interactions with the surrounding micro-environment. Bull Cancer, 95, 301-13.

Carl A, Burtis, Edward R, et al (1999). Tietz Text book of clinical chemistry, $3^{\text {rd }}$ Ed, Philadelphia: W.B. Saunders 1400.

Durie G, Kyle A, Belch A, et al (2003). Myeloma management guidelines: a consensus report from the scientific advisors of the international myeloma foundation. Hematol J , 4, 379-98.

DuVillard L, Guiguet M, Casasnovas O, et al (1995). Diagnostic value of serum IL-6 level in monoclonal gammopathies. $\mathrm{Br}$ J Haematol, 89, 243-9.

Estimated Cancer Incidence, Mortality and Prevalence in 2012. Available at http://globocan.iarc.fr/Pages/fact_sheets_ population.aspx. Accessed: May 2014.

Fragioudaki M, Boula A, Tsirakis G, et al (2012). B cellactivating factor: its clinical significance in multiple myeloma patients. Ann Hematol, 91, 1413-8.

Greipp R, San Miguel J, Duries M, et al (2005). International Staging System for multiple myeloma. J Clin Oncol, 23, 3412-20.

Gupta M, Han J, Stenson M, et al (2012). Elevated serum IL-10 levels in diffuse large B-cell lymphoma: a mechanism of aberrant JAK-2 activation. Blood, 119, 2844-53.

Hengeveld J , Kersten J (2015). B-cell activating factor in the pathophysiology of multiple myeloma: a target for therapy? Blood Cancer J, 27, 282.

Hirano T (2014). Revisiting the 1986 molecular cloning of interleukin 6. Front. Immunol, 5, 456.

Horii Y, Muraguchi A, Suematsu S, et al (1988). Regulation of BSF-2/IL-6 production by human mononuclear cells. $J$ Immunol, 141, 1529-35.

Kim E, Yoo C, Lee H, et al (2010). Serum albumin level is a significant prognostic factor reflecting disease severity in symptomatic multiple myeloma. Ann Hematol, 89, 391-7.

Kovacs E (2010). Interleukin-6 leads to interleukin-10 production in several human multiple myeloma cell lines. Several human multiple myeloma cell lines. Does interleukin-10 enhance the proliferation of these cells? Leuk Res, 34, 912-6.

Kyle A, Gertz A, Witzig E, et al (2003). Review of 1027 patients with newly diagnosed multiple myeloma. Mayo Clin Proc, 78, 21-33.

Lauta M (2003). A review of the cytokine network in multiple myeloma. Cancer, 97, 2440-52.

Lemancewicz D, Bolkun L, Jablonska E, et al (2013). Evaluation of TNF superfamily molecules in multiple myeloma patients:Correlation with biological and clinical features. Leuk Res, 37, 1089-93.

Moore W, O'Garra A, de Waal R, et al (1993). Interleukin-10. Annu Rev Immunol, 11, 165-90.

Moreaux J, Legouffe E, Jourdan E, et al (2004). BAFF and APRIL protect myeloma cells from apoptosis induced by interleukin 6 deprivation and dexamethasone. Blood, 103, 3148-57.

Moreau P, San Miguel J, Ludwig H, et al (2013). Multiple Myeloma: ESMO Clinical Practice Guidelines, Ann Oncol, 24, 133-7.

Multiple Myeloma: Statistics (2015). Available at: http://www. cancer.net/cancer-types/multiple-myeloma/statistics.

Okada M, Kitahara M, Kishimoto S, et al (1988). I1-6/BSF-2 functions as a killer helper factor in the in vitro induction of cytotoxic T cells. J Immunol, 141, 1543-9.

Oken M, Creech H, Tormey C, et al (1982). Toxicity and response criteria of the eastern cooperative oncology group. Am J Clin Oncol, 5, 649-55.

Pika T, Minarik J, Schneiderka P, et al (2008). The correlation of serum immunoglobulin free light chain levels and selected biological markers in multiple myeloma. Biomed Pap Med Fac Univ Palacky Olomouc Czech Repub, 152, 61-4.

Sirohi B, Powles R, Kulkarni S, et al (2001). Comparison of new patients with Bence-Jones, IgG and IgA myeloma receiving sequential therapy: the need to regard these immunologic subtypes as separate disease entities with specific prognostic criteria. Bone Marrow Transplant, 28, 29-37.

Sirohi B, Powles R (2004). Multiple myeloma. Lancet, 363, 875-87.

Solomon A (1976). Bence-Jones proteins and light chains of immunoglobulins (first of two parts). N Engl J Med , 294,17-23.

Solomon A (1986). Clinical implications of monoclonal light chains. Semin Oncol, 13, 341-9.

Tinhofer I, Marschitz I, Henn T, et al (2000). Expression of functional interleukin- 15 receptor and autocrine production of interleukin-15 as mechanisms of tumor propagation in multiple myeloma. Blood, 95, 610-8.

Tricot G (2000). New insights into the role of microenvironment in multiple myeloma. Lancet, 355, 248-50.

Weissenbach J, Chernajovsky Y, Zeevi M, et al (1980). Two interferon mRNAs in human fibroblasts: In vitro translation and Escherichia coli cloning studies. Proc Natl Acad Sci USA, 77, 7152- 6.

Wang M, Zhang L, Jiang M, et al (2011). Expression and significance of B cell-activating factor of TNF family (BAFF) and B cell lymphoma/leukemia-2 (BCL-2) in multiple myeloma. Zhongguo Shi Yan Xue Ye Xue Za Zhi, 19, 395-8. 